\title{
In-Situ Transmission Electron Microscopy on Operating Electrochemical Cells
}

Gualandris, Fabrizio; Simonsen, Søren Bredmose; Mogensen, Mogens Bjerg; Mølhave, Kristian; Sanna, Simone; Wagner, Jakob Birkedal; Kuhn, Luise Theil

Publication date:

2016

Document Version

Peer reviewed version

Link back to DTU Orbit

Citation (APA):

Gualandris, F., Simonsen, S. B., Mogensen, M. B., Mølhave, K., Sanna, S., Wagner, J. B., \& Kuhn, L. T. (2016). In-Situ Transmission Electron Microscopy on Operating Electrochemical Cells. Abstract from 16th European Microscopy Congress, Lyon, France.

\section{General rights}

Copyright and moral rights for the publications made accessible in the public portal are retained by the authors and/or other copyright owners and it is a condition of accessing publications that users recognise and abide by the legal requirements associated with these rights.

- Users may download and print one copy of any publication from the public portal for the purpose of private study or research.

- You may not further distribute the material or use it for any profit-making activity or commercial gain

- You may freely distribute the URL identifying the publication in the public portal

If you believe that this document breaches copyright please contact us providing details, and we will remove access to the work immediately and investigate your claim 


\title{
IN-SITU TRANSMISSION ELECTRON MICROSCOPY ON OPERATING ELECTROCHEMICAL CELLS
}

\author{
Authors: Fabrizio Gualandris (1), Søren Bredmose Simonsen (1), Mogens Bjerg Mogensen (1), \\ Kristian Mølhave (2), Simone Sanna (1), Jakob Birkedal Wagner (3), Luise Theil Kuhn (1) \\ 1. DTU Energy, Technical University of Denmark, Roskilde, DENMARK \\ 2. DTU Nanotech, Technical University of Denmark, Kgs. Lyngby, DENMARK \\ 3. Center for Electron Nanoscopy, Technical University of Denmark, Kgs. Lyngby, DENMARK
}

DOI: 10.1002/EMC2016.0823

Corresponding email: fabbry.guala@gmail.com

Keywords: In-situ TEM, SOFC, SOEC, LSC, YSZ

Solid oxide cells (SOC) have the potential of playing a significant role in the future efficient energy system scenario. In order to become widely commercially available, an improved performance and durability of the cells has to be achieved [1]. Conventional scanning and transmission SEM and TEM have been often used for ex-situ post mortem characterization of SOFCs and SOECs [2,3]. However, in order to get fundamental insight of the microstructural development of SOFC/SOEC during operation conditions in-situ studies are necessary [4]. The development of advanced TEM chips and holders makes it possible to undertake analysis during exposure to the SOFC/SOEC sample of reactive gas flow, elevated temperatures and electrical biasing in combination. This allows the study of nanostructure development under temperature and electrode polarisation conditions similar to operation conditions.

In this work, we have for the first time performed in-situ analysis of a symmetric cell inside a TEM under different configurations. In order to be able to perform in-situ experiments while drawing a current through the sample, we used a homemade TEM chip [5,6] and an 80-300kV Titan ETEM (FEI Company) equipped with an image corrector and a differential pumping system.

A symmetric cell was prepared by depositing a cell consisting of three thin films on a strontium titanate (STO) single crystal substrate by pulsed laser deposition (PLD). Lanthanum strontium cobaltite $\mathrm{La}_{0.6} \mathrm{Sr}_{0.4} \mathrm{CoO}_{3.6}$ (LSC) was chosen as electrode and yttria stabilized zirconia $\mathrm{ZrO}_{2}: 8 \% \mathrm{~mol}_{2} \mathrm{O}_{3}(\mathrm{YSZ})$ as electrolyte, see figure 1. High resolution TEM analysis on PLD samples after the deposition, did not reveal any second phase formation at the interface between YSZ and LSC. The in-situ experiment was firstly conducted in vacuum at temperature between $25{ }^{\circ} \mathrm{C}$ and $900{ }^{\circ} \mathrm{C}$. Secondly, it was repeated in presence of oxygen with an oxygen partial pressure of about 2 mbar and a maximum temperature of $750^{\circ} \mathrm{C}$. Subsequently, the symmetric cell will be exposed to oxygen at $600{ }^{\circ}$ $\mathrm{C}$ and $1 \mathrm{~V}$ overpotential within the ETEM. In order to do that, a symmetric cell has been placed on the chip with the use of a focus ion beam (FIB) microscope, see figure 2. To do so, a lamella was first extracted by the bulk sample and attached to a conventional TEM grid. Afterwards, the grid was tilted by 90 degrees and the lamella was detached once again and placed on the chip.

STEM-EDS investigation was used for ex-situ post mortem analysis. Finally, a bulk symmetric cell, coming from the same batch as the in-situ treated TEM samples, was tested in a furnace with similar environmental conditions. This comparison is vital for distinguishing possible surface diffusion effects caused by having a thin lamella for in-situ TEM analysis. Electrochemical properties were also investigated by electrochemical impedance spectroscopy (EIS).

In the figure 3 the cell was heat treated at $400{ }^{\circ} \mathrm{C}$ in vacuum, whereas in figure 4 , the cell was treated at the same temperature but in presence of oxygen, with $\mathrm{PO}_{2}$ of 2 mbar. Comparing the two figures, the cell exposed to oxygen showed structural changes in the LSC thin film in comparison with the sample heated in vacuum. These changes refer to the formation of grains as is confirmed by electron diffraction patterns.

[1] A. Atkinson et al., Nature Materials 2004, 3, 17-27.

[2] R. Knibbe et al., Journal of The Electrochemical Society 2010, 157, B1209-B1217.

[3] N. Imanishi et al., Solid State Ionics 2006, 177, 2165-2173.

[4] M. L. Traulsen et al., ECS Transactions 2015, 66, 3-20.

[5] C. Kallesøe et al., Nano Letters 2012, 12, 2965-2970.

[6] S. B. Alam et al., Nano Letters 2015, 15, 6535-6541. 


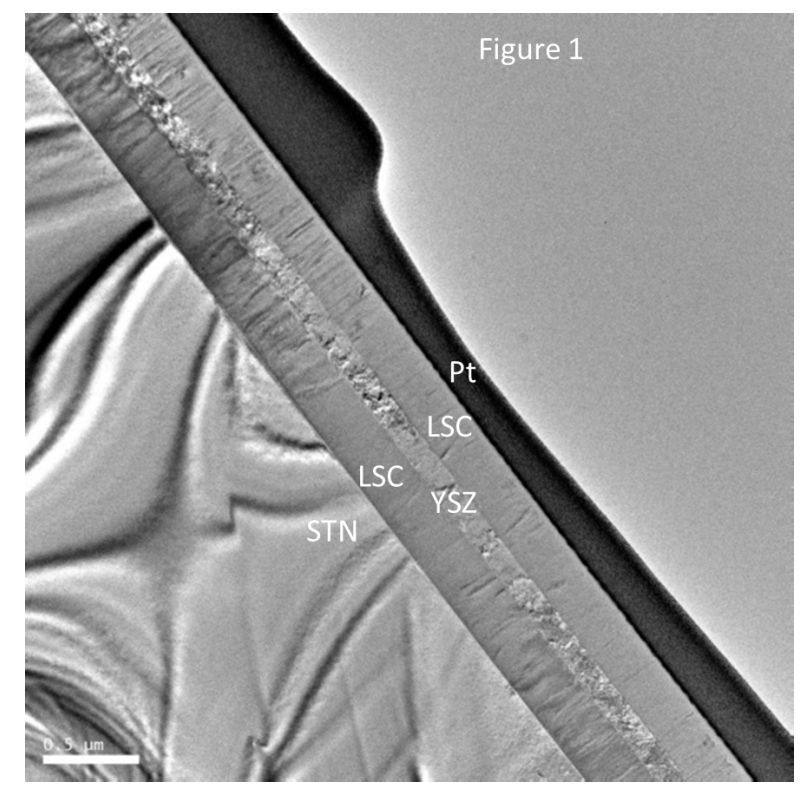

TEM image of a solid oxide symmetric cell grown by PLD on a single crystal substrate of STN.

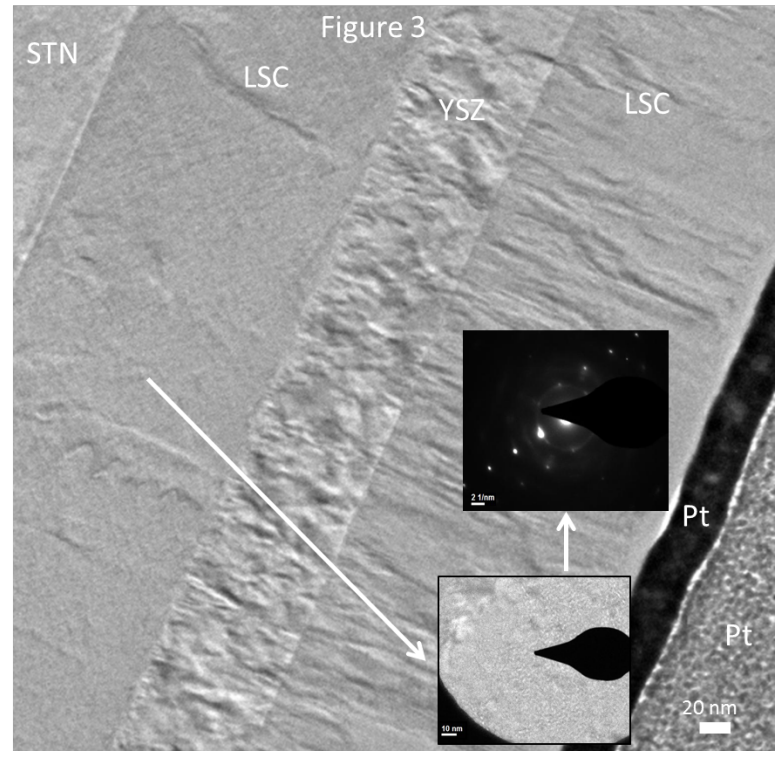

TEM image of a symmetric cell exposed at $400 \mathrm{C}$ in vacuum. The insets showed a higher magnification image of the LSC thin film and its equivalent diffraction pattern.

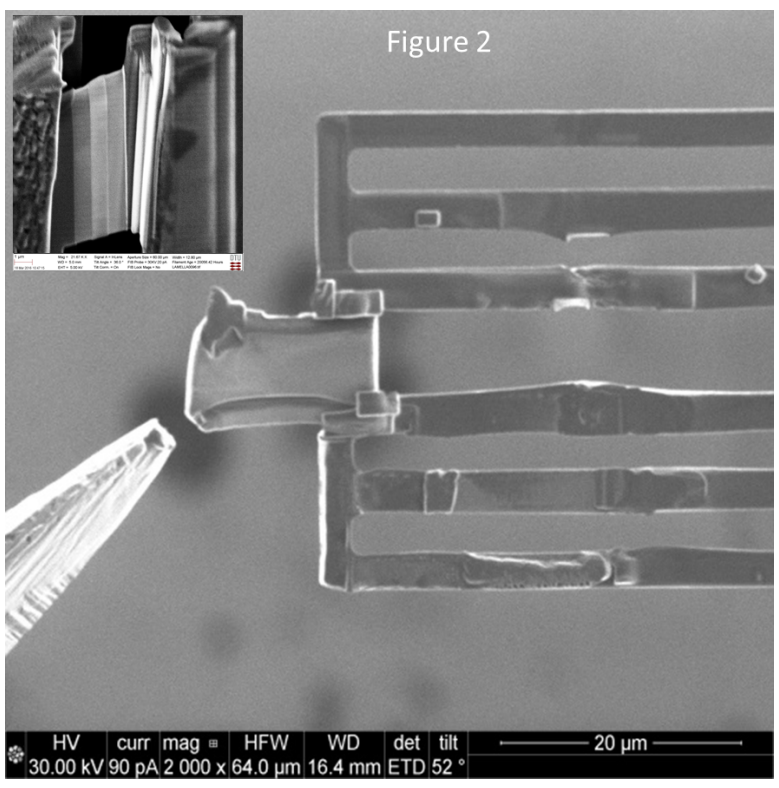

Symmetric cell placed on a homemade TEM chip by FIB. The layers are visible in the inset, after the removing of the material re-deposition during the milling job.

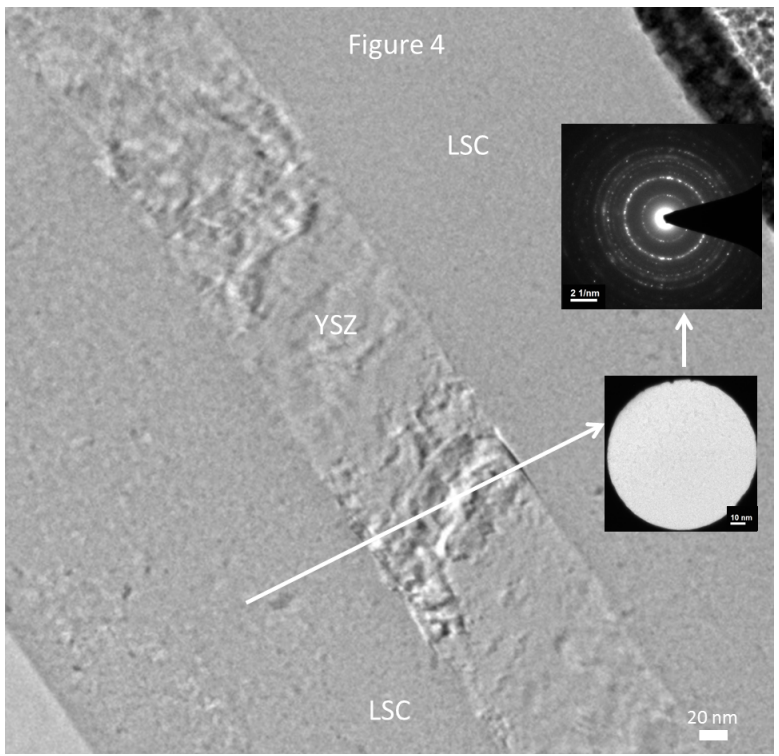

TEM image of a symmetric cell exposed to $400 \mathrm{C}$ in oxygen, with $\mathrm{PO} 2=2$ mbar. LSC is polycrystalline as confirmed by the diffraction pattern made on a magnified area of the LSC thin film. 